\author{
MAGDALENA STOCHNIOL \\ https://orcid.org/0000-0002-9973-0964 \\ Chair of Composition and Theory of Music, Karol Szymanowski Academy of Music in Katowice
}

\title{
Intercultural Musical dialogue in St John Passion by Sofia Gubaidulina
}

\begin{abstract}
Sofia Gubaidulina is one of the most important composers living today. Among her many works acknowledged and awarded prizes on the international forum, the diptych St John Passion and St John Easter [The Resurrection of Christ according to St John], the opus magnum of that outstanding Russian composer, occupies a special place. This work focuses the most important features of her music, such as a profound theological message based on a compilation of fragments from the Old Testament, Gospels and the Apocalypse of St John, as well as her musical rootedness in the cultural tradition of the churches of both East and West. Gubaidulina adapts the achievements of the artistic avant-garde in new and original ways, while at the same time she is an ardent champion of traditional universal values grounded in the message of the Bible and Christian cultural tradition. This paper presents St John Passion by Sofia Gubaidulina in the context of its theological and intercultural dialogue, as well as attempting to characterise the phenomenon represented by this composer, who raises anew reflection on the fate of humankind in the context of existential questions, while remaining faithful to the idea of high art, exquisite and open to various understandings of the idea of beauty.
\end{abstract}

KEYWORDS: Gubaidulina, St John Passion, theological dimension of the text, sacrum, Orthodoxy

To begin with the banal statement that Sofia Gubaidulina is one of the most important living composers might be regarded both as a cliché and too much of a generalisation. After all, how else could one describe a composer who has almost one hundred and fifty works in her portfolio, who writes for the top world orchestras, who receives awards from the most prestigious foundations, and whose commissions diary is always full for months ahead. The point of interest here then is not just the importance and significance of Gubaidulina's compositions, which in the context described above seem unquestionable, but the path which led her to this moment of universal acknowledgment.

Almost from the very beginning, and throughout all the years of being active as a composer, Gubaidulina's works were seen in the context of her generation whose common denominator was the place of birth and its registration. Clearly we are talking about Arvo Pärt, Alfred Schnittke, Edison Denisov and Valentin Silvestrov, to mention just the most important artists representing the states of the former USSR and born towards the end of the 1920s and 1930s. Even though 
each of them is stylistically distinctive, there is no doubt that the political situations which they had to face in their early years, followed by the dissolution of the Soviet Union and the possibility of opening to Europe that that event brought about, was a common element which determined the choices they made. Peter J. Schmeltz (2009), in his excellent book Such Freedom, if only musical, describes a number of phenomena relating to concert life, as well as social and political life, and provides an answer regarding the path travelled by these composers. He concludes that one element of the key change was based on moving from abstraction to mimesis and from control to freedom. These features might also be enhanced by the change, so significant for each of them, from materialism to spirituality.

The use of these last contrasting concepts requires a brief exposition. The two terms, materialism and spirituality, may be interpreted in a variety of ways. In order to avoid misunderstandings, I specify the sense in which they are used here. Materialism in this article is understood as focusing on music material, fully and exclusively, as the most important building blocks of the composition. Moving around in a space 'outside meaning' in order to make use of sound-initself and of new techniques. To be specific: the case of Pärt has been thoroughly researched. In his early works he would, for example, start with using series as the basis for shaping a composition, and then reach what might be seen as a kind of creative manifesto in 1968, when he wrote Credo, to be followed by a turning point in technique and aesthetic, first revealed in his Für Alina for piano, written in 1976. We find similar developments in the case of Denisov and Schnittke.

Gubaidulina travelled a similar path, but with one caveat. Yes, her early works, as in the case of the composers referred to above, start with the adoption of dodecaphonic or even serial models, but the expression which she succeeds in achieving within the framework of these techniques is totally different. The dodecaphonic cantata Night in Memphis, written, like Pärt's Credo, in 1968, may serve as an example here. The textual base of the work is provided by Old Egyptian poetry translated by Anna Akhmatova. In spite of using more modern techniques, a lyrical note permeates the composition; it is deep, independent of the dodecaphonic order, and constitutes the essence and the core of this music. Cholopova (1974, pp. 124-128, as cited in Schmeltz, 2009, p. 264) notes that, although the cantata was written before 1971, i.e., before Gubaidulina was baptised, it already carries a spiritual, or even sacred element, perceptible in her earliest works and independent of the technique used.

The term 'spirituality' used in this context, in spite of numerous attempts to define this concept by various authors, still causes a few problems. If we assume that it is music that is not absolute, but determined by external factors such as the composer's religiosity, meditative character or deep emotionality, we still feel that this definition is not full and not complex enough. Bohdan Pociej (2004, p. 45), in his reflections on spirituality, suggests that we see it as music born 'out of profound metaphysical intuitions, for which the sound form - made concrete in its timbre and sound structure - is also equivalent to an act (acts) of faith made real in religious symbols'. In this definition Pociej links spirituality and sound, and this indicates that a deep and full understanding of spirtuality may 
be revealed through true, authentic creativity, often attempting to capture the truth about the Absolute.

This spiritual transformation which led to the spiritual dimension of Gubaidulina's compositions begins to reveal itself most clearly from the 1970s. In 1971 she is baptised in the Orthodox Church and from that moment she declares in many published statements that her work is totally religious. What makes her approach to the issue attractive is its literal interpretation. For Gubaidulina, the word religion derives from the dictionary meaning of 're-ligio' and is explained as a renewal of the bond between man and God. This interpretation is deepened by referring the second segment of the word - ligio - to musical legato, and in this way confirming even more strongly that musical creations may express this spiritual space in a specific way (Lukomsky, 1988, p. 34). Undoubtedly the culmination of this development was the writing of St John Passion (2000), and later also St John Easter [The Resurrection of Christ according to St John] (2002). These works fully capture that spiritual dimension of art, as well as allowing one to appreciate the phenomenon of outstanding artistry.

The composition was commissioned by Helmut Rilling and the Bach Academy in Stuttgart as part of the Passion 2000 project. The main idea of the project was to celebrate the 250th anniversary of the death of Johann Sebastian Bach, but the choice of the passion genre was intended as a reminder - at the turn of the millennium - of the 'roots' of European 'serious' music, linked to liturgy and biblical themes. ${ }^{1}$

To provide better understanding of the profound theological message of the Passion it is worth quoting a fragment of the composer's commentary on the work. She said that when accepting the commission she planned from the beginning to compose another, extended work on Christ's resurrection, having decided that the dramatic story of Jesus, His suffering and death make sense only in the context of his later resurrection. According to the composer:

The initial conception of Johannes-Passion from its inception also contained a musical representation of resurrection. This should in every way, more than all the other fragments, be based on the mutual influence of two texts: the story of the Gospel according to St John and St John's Apocalypse. That part about the resurrection, originally planned as the final one, developed into a full passion composition and, to a large extent, it explains its specific structure through the specific order of texts of the Gospel and the Apocalypse. However, while working on the Passion I had to separate my thoughts about the resurrection from the passion itself. This is what I felt: the story of Jesus's earthly life path should in no way end with a 'solution of the dramatic conflict'; after events so dramatic you could only follow by one thing: a sign of the Final Judgment, or extreme dissonance, a kind of scream. And after this final scream there was just one thing to think: silence. There is no continuation and there cannot be: 'It has been fufilled'. However, the composition as a whole needed an ending. And so I decided to find an honest answer to the events of the passion which seems so impossible from the point of view of psychology (Gubaidulina, 2002, pp. 25-26).

\footnotetext{
${ }^{1}$ Other works produced within the framework of this project, alongside Gubaidulina's St John Passion, included Deuss Passus by Wolfgang Rihm, Pasión según san Marcos by Osvaldo Golijov and Water Passion by Tan Dun.
} 
The form of the work divides into two parts, with a caesura after part VII. Parts I-VII present the events which precede the Way of the Cross, beginning from the moment of the Last Supper until Pilate's judgement of Jesus. Parts VIII-XI present the Way of the Cross, death and entombment of Christ. Among the eleven parts of the Passion only three refer explicitly to the passion events (VII, VIII, X). Part VIII makes use also of the text of the Apocalypse, and part VII - text from the Old Testament. In turn, in parts VI, IX and XI the text of the Apocalypse is dominant, supplemented in parts IX and XI by a verse from the Gospel according to St John. Three scenes (parts III, IV, V) refer to the gospel virtues (faith - hope - love), and the other two scenes (parts I and II) emphasise Christ's divinity as the Word of God on the one hand (in part I the initial verses of the Gospel according to St John), and on the other - an example of Christ's humility (in part II The washing of the feet the text of the Gospel is studded with fragments of text taken from the Apocalypse and the Old Testament). The following were taken from St John's Revelation: (1) scene representing Christ as Lamb of God sitting on a throne and opening consecutive seals (the vision of the symbolic four horses of different colours: white, the colour of fire, black and the pallor of death, Apocalypse chapters 7 and 19); (2) scene showing Angels bringing down the plague on Earth (Apocalypse, chapters 8-9); (3) scene showing a Woman clothed with the sun (Apocalypse, chapters 11-12); and (4) scene representing judgment on the world: 'bowls of plagues' being poured over the world (Apocalypse, chapters 10 and 16).

Example 1. St John Passion, textual sources

\begin{tabular}{|l|l|l|l|l|}
\hline Part & \multicolumn{1}{|c|}{ Title of Part } & Gospel Source & \multicolumn{1}{|c|}{$\begin{array}{c}\text { Apocalypse } \\
\text { Source } \\
\text { Books of } \\
\text { the Bible }\end{array}$} \\
\hline P. I & The Word & John 1 & & \\
\hline P. II & The washing of the feet & John 13 & Apoc 7 and 19 & Heb. 10 \\
\hline P. III & Commandment of faith & John 14 & & \\
\hline P. IV & Commandment of love & John 15 & & \\
\hline P. V & Hope & John 17 & & Heb. 10, Is 53 \\
\hline P. VI & Liturgy in Heaven & & Apoc $4-7$ and 19 & \\
\hline P. VII & $\begin{array}{l}\text { Betrayal, denial, } \\
\text { flagellation, condemnation }\end{array}$ & John $18-19$ & & \\
\hline P. VIII & The road to Golgotha & John $4-5,79-10$ & Apoc $8-9$ & \\
\hline P. IX & Woman clothed in the sun & Jn 19 & Apoc 11-12 & \\
\hline P. X & $\begin{array}{l}\text { Entombment } \\
\text { (John } 19 \text { also } 1\end{array}$ & & \\
\hline P. XI & Seven bowls of wrath & Jn 1 & Apoc 10 and 16 & \\
\hline
\end{tabular}

Source: own study. 
The compilation of texts used by Gubaidulina highlights the general message to show that she associates the dramatic events of betrayal and passion at the Golgotha with the essence of Christ's teaching. She links these images to a vision of victory of those who imitate the life of Christ. Christ's Mother (part IX Woman clothed in the sun) is shown not as Mother of Sorrows (as, for example, in the Stabat Mater sequence), but as an apocalyptic sign of victory. On the other hand, the scenes of the Last Judgment as 'the day of wrath' are a warning to those who ignore this message.

The idea of combining two sources from John - the Gospel and the Apocalypse - is one of the most interesting aspects of the work. The new, authorial construction of the text led to an 'expanded' and full theological interpretation: the chosen verses complement each other, providing 'responses' to each other. This may be illustrated by Part VIII. The Gospel and Apocalypse texts mentioned earlier are interspersed with fragments from the Book of Isaiah and the Epistle to the Hebrews. The narration becomes complex and multi-layered. The Old Testament is interpreted in the light of the New one, and including St John's Apocalypse in the proposed arrangement reveals inexhaustible sources of inspiration of the Holy Writ. The use on many occasions of recurring sentences as commentary on the 'main' text emphasises the theological dimension of the 'stages' of the gospel idea being fulfilled (Redepenning, 2002, p. 97).

Example 2. St John Passion, part VIII, comparison of textual sources, initial fragment ${ }^{2}$

\begin{tabular}{|c|c|c|c|}
\hline \multicolumn{4}{|c|}{ The Way to Golgotha } \\
\hline Voice & Text & Chorus I & Chorus II \\
\hline Bass: & So they took Jesus... (John 19) & & \\
\hline Baritone: & $\begin{array}{l}\text { The first angel blew his trumpet, } \\
\text { and there came hail and fire, mixed } \\
\text { with blood, and a third of the } \\
\text { earth was burned up. (Rev. 8) }\end{array}$ & 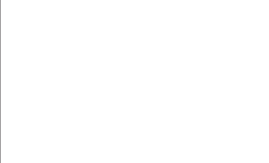 & \\
\hline Bass: & $\begin{array}{l}\text { He is carrying the cross by } \\
\text { himself (John 19) }\end{array}$ & 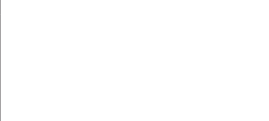 & $\begin{array}{l}\text { This man is a sinner. } \\
\text { (John 9) }\end{array}$ \\
\hline & & $\begin{array}{l}\text { How can a man who } \\
\text { is a sinner perform } \\
\text { such signs? (John 9) }\end{array}$ & 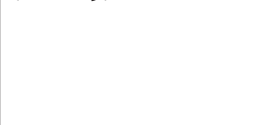 \\
\hline Baritone: & $\begin{array}{l}\text { The second angel blew his } \\
\text { trumpet, and something like } \\
\text { a great mountain, burning with } \\
\text { fire, was thrown into the sea. } \\
\text { (Rev. 8) }\end{array}$ & \begin{tabular}{|l} 
If this man were not \\
from God, he could \\
do nothing. (John 9)
\end{tabular} & $\begin{array}{l}\text { He is out of his mind. } \\
\text { He has a demon } \\
\text { (John 10) }\end{array}$ \\
\hline
\end{tabular}

${ }^{2}$ English translation of Johannes-Passion, by Laurel E. Fay, came from booklet to CD (con. Valery Gergiev, Hänssler classic label, 2000). 


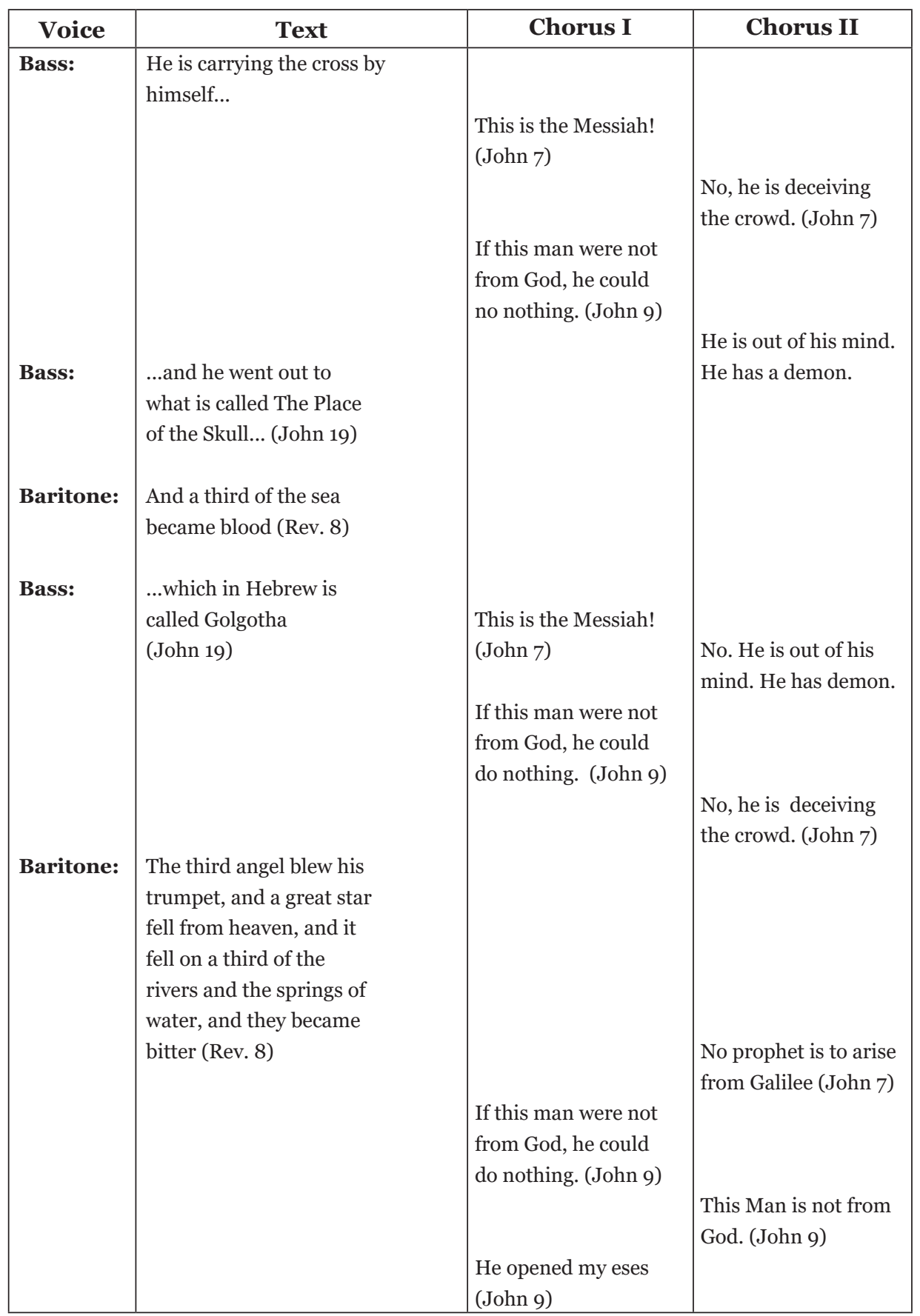

Source: own study.

However, the issue of setting the events of the passion to music by Gubaidulina has a wider dimension, since there is no tradition of performing the passion 
in the Orthodox church. ${ }^{3}$ This problem influenced the approach to performance scoring, different from the passion music of the West. The dramatic action involves four solo voices (soprano, tenor, baritone and bass), two mixed choirs with varied scoring and an expanded score for a symphony orchestra, enriched by percussion instruments and less popular wind instruments (such as Wagner tubas). The change of the role and character of the performance cast is polarised in two fundamental ranges: the musical shaping of time, different from the Western one and linked to its contemplative character belonging to the Eastern tradition, and different dramaturgy. To quote the composer:

In a sense my music is also de-dramatised. I wanted all the performers - musicians, soloists, the orchestra - to be narrators... as if the evangelists. This is a different conception from that in Bach [...] The whole composition is epic. The drama is between heaven and earth. In the text itself we do not deal with drama: everybody is narrating, as if they were sitting around, someone is commenting, someone adds something... This is a kind of story-telling (Cichy \& Stochniol, 2008, p. 6).

In this conception there is no division into parts, and in the solo voices the criterion for the musical setting became the source of the text - the Gospel or the Apocalypse. The bass and the tenor realise almost exclusively the text of the Gospel, while the baritone and the soprano that of St John's Revelation. This gives rise to two independent 'musical visions', in which the events take place in two worlds: of Earth and of Heaven. This division is equally apparent for the audience, since it is linked to using particular musical strategies. Events relating to the crucifixion are presented with what seems like detachment, while the apocalyptic visions use expressive musical techniques. The bass presents the text of the Gospel in low register, slowed down time, the melodics rely on diatonic or segments of modal scales, and the rhythm on long regular values. The meditative, almost ritual character of this melodeclamation is achieved through repetition of melodic phrases, centralisation around one note, pendular and monotonous motion. The singing has to follow the verbal accents, and the text is presented syllabically. There is no effect of striving or culmination or building up tensions. All these techniques bring to mind a priest conducting a religious service and have the character of a kind of ritual.

The apocalyptic fragments provide total contrast to the gospel ones. That contrast is realised in the plane of intervals, scale and dynamics. It relates to the solo parts of the baritone and the soprano, exceptionally also to the tenor. Chromaticism dominates, as well as wide interval leaps and small and irregular rhythmic values. The turbulent character is emphasised by the instrumental part through the use of expanded instrumentation and multi-layered texture. The different way

\footnotetext{
3 'From the very beginning I realised the fundamental difficulties encountered when writing the Passion in Russian. The tradition of the Russian Orthodox church does not allow the use of instruments - not during mass, nor any other church celebrations. There is no external, technical intermediary between man and God at all - only one's own voice and a candle in one's hand. However, the most important thing is that in the Orthodox church there is no tradition of performing the Passion at all. To the Russian way of thinking «represented art» was always regarded as secondary to the «art of direct experience»'. 'Church traditions reject any reference to the art of representation of a theatrical nature' (Anderson, 2003).
} 
of treating the melodic aspect is also emphasised by the dynamic element and the use of high register stressing the expression of the phrases of solo parts.

As well as the issues described earlier, the problem of the musical rootedness of the Passion is also of significance. In interviews Gubaidulina stresses that she belongs to a number of cultures: Russian, Tatar, Jewish and German. In a documentary filmed by the BBC she says:

I feel I'm a mixture not just of two bloods, but of four. On my father's side I am a Tatar and on my mother's side I am Slavic. But a large role was played in my life by the director of the music school. I took him as a second father - this is my Jewishness. And my spiritual nourishment came from German culture - Goethe, Hegel, Novalis, Bach, Webern, Haydn, Mozart, Beethoven... There was such a diversity of origins inside me (Gavin, 1990).

Taking up the Passion theme thus involves a very specific perspective, of a composer whose religion is Eastern Orthodoxy, who has intense contacts with Western culture also because she lives in German and is strongly influenced by the works of Bach. The choice of the National language as the basis of the Passion and Resurrection points to links to the tradition of Bach and the need for the text to be comprehensible. On the other hand, the choice of fragments from St John's Gospel and Apocalypse indicates a profoundly theological bond with the Orthodox liturgy, since the structure and the message of the text stay close to the Orthodox conception of 'small and great entries' (Evdokimov, 2003, p. 259), symbolising the gradual deepening of the focus of those participating in the liturgy. The faithful are witnesses to and participants in the unfolding liturgical events. It is thus not a repetition or a remembrance of the Eucharistic feast which took place centuries ago; rather, the Eucharistic Offering takes place anew in every temple and at every time. The events of the Gospel and the Apocalypse happen 'beyond time', as they do beyond space, each time anew. As we know, the symbol of opening, the three doors, is contained within the iconostasis. The priest who conducts the ceremony at different points goes through the door, and each consecutive entry symbolises entering more deeply into the mysteries of Christ and purification, equivalent to coming closer to and to the union with God. The symbol of the door also signifies moving into a different dimension, the dimension of a parallel - heavenly - space.

One of the examples in the text which shows this symbolic 'entry' is the moment when the dramatic action begins - part II The washing of the feet. This image may be linked to a symbolic reference to the original purification of man through baptism. In turn, the sacrament of baptism itself is linked to purification symbolising entry into a congregation, acceptance by a congregation, inclusion within the community. We find another example of symbolic purification in the beginning of part VI Liturgy in Heaven. Gubaidulina again refers to the symbol of a door, and that part begins with the words 'behold, a door was opened in heaven' (Apoc 4:1).

Eastern and Western traditions differ from each other on a number of issues. The Eastern church is more mystical, focused on direct experience of the presence of God. It therefore rejects that which is external, and reaches towards the inner experience, hence in liturgy free narration, entry into the sacred time, is dominant. In relation to liturgy we may talk of existential time (Evdokimov, 
2003, p. 220) that allows one to open to another dimension, and the concept of time and being beyond temporality is found in a number of elements, such as the verbal ones, the liturgical rite. Interpreting the essence of the Eucharistic Offering in liturgy, Evdokimov (2003, p. 260) draws attention to the essential link to and meaning of the apocalyptic message. He finds the essence of the message only when the two images (the Eucharist and the Apocalypse) are combined. Theodore of Mopsuestia ${ }^{4}$ emphasises the existence of two different levels of reality: 'It is not something new, but the liturgy which takes place in heaven, during which we also are in heaven' (Evdokimov, 2003, p. 222). The closeness between these words and Gubaidulina's interpretation and linking of the Gospel with the Apocalypse, as well as including the Liturgy in Heaven as one of the parts of St John Passion, demonstrates that the composer was familiar with this strictly theological interpretation.

Example 3. Intercultural music dialogue between West and East

\begin{tabular}{|c|c|c|}
\hline \multirow{2}{*}{ Were } & \multicolumn{2}{|c|}{ Intercultural music dialogue } \\
\hline & West & East \\
\hline In the text & $\begin{array}{l}\text { - Passion as a genre connected } \\
\text { with Western cultural tradition } \\
\text { and the music of Johann Sebas- } \\
\text { tian Bach }\end{array}$ & $\begin{array}{l}\text { - resignation of representa- } \\
\text { tion and drama } \\
\text { - timeless - construction of } \\
\text { the text refers to history on } \\
\text { the Earth and in Heaven } \\
\text { - concepction of small and } \\
\text { great entries }\end{array}$ \\
\hline In the music & $\begin{array}{l}\text { - dramatic tension in the baritone } \\
\text { and the soprano parts } \\
\text { - wide interval leaps, irregular } \\
\text { rhythmic values, high register }\end{array}$ & $\begin{array}{l}\text { - meditative character of the } \\
\text { bass solo parts, refers to basso } \\
\text { profondo from Orthodox } \\
\text { church liturgy } \\
\text { - low register, melodic } \\
\text { scales, based on } 3 \text { or } 4 \text { tones } \\
\text { structures as a connection } \\
\text { with ritual and the Orthodox } \\
\text { church liturgy }\end{array}$ \\
\hline
\end{tabular}

Source: own study.

Sofia Gubaidulina's artistic personality and her work as composer provide interesting evidence of an individual amalgamation of the legacy of twentiethcentury avant-garde with the tradition of European musical culture. She is linked to the avant-garde not only by her use of innovative articulation or cluster

4 Theodore of Mopsuestia, also known as Theodore of Antioch (350-428), early Christian theologian, bishop of Mopsuestia. At the centre of his theology are deliberations on the two natures of Christ. 
sound bands but also by her fascination with the possibility of subordinating the process of composing to selected numbers or ratios. Within the European musical heritage the composer focuses on Johann Sebastian Bach, admires both the mastery of his compositions and giving artistic witness to profound belief in the gospels' story of life, death and resurrection of Christ. Gubaidulina adapts the achievements of the artistic avant-garde in new and original ways, but she does not share its worldview, associated with such ideas as nihilism or revolutionary re-assessment of traditional values. On the contrary, having experienced the terror of communist enslavement, the composer became a committed champion of traditional universal values grounded in the message of the Bible and Christian cultural tradition. Her published statements not only give witness to her direct observation of the time of communist terror, but provide an example of determined opposition to the totalitarian machine. They are also an individual manifestation of an almost mystical understanding of the experience of sound interpreted in the categories of a religious experience. Gubaidulina fascinates by her commitment to the shaping of a culture that would take up again reflection on the fate of humanity in the context of existential questions; a culture that is also faithful to the idea of high art, exquisite and open to various understandings of the idea of beauty.

Translated by Zofia Weaver

\section{References}

Anderson, M. (2003). From the BBC Proms Festival, (B. Bolesławska, Transl). In Książka programowa 46. Międzynarodowego Festiwalu Muzyki Wspótczesnej Warszawska Jesień, 2003 [Programme Book 46 of the Warsaw Autumn Internation Festival of Contemporary Music, 2003] (pp. 262-265). Warszawa: [Warszawska Jesień].

Cichy, D., \& Stochniol, M. (2008). Między Ewangelią a ciągiem Fibonacciego [Between the Gospel and Fibonacci's Sequence]. Ruch Muzyczny, 2: 6.

Gavin, B. (Director). (1990). Fire and the Rose, Portrait of Sofia Gubaidulina [Film]. BBC.

Gubaidulina, S. (2002). In meinem Ende liegt der Anfang zu meinem Stück Johannes-Ostern. Musiktexte, 93: 25-26.

Książka programowa 46. Międzynarodowego Festiwalu Muzyki Wspótczesnej Warszawska Jesień, (2003). [Programme Book 46 of the Warsaw Autumn Internation Festival of Contemporary Music, 2003] (pp. 260-265). Warszawa: [Warszawska Jesień].

Evdokimov, P. (2003). Prawostawie [Orthodoxy], (J. Klinger, Trans.). Warszawa: Instytut Wydawniczy PAX.

Lukomsky, V. (1998). 'The Eucharist in My Fantasy': Interview with Sofia Gubaidulina. Tempo. New Series, 206: 29-35.

Pociej, B. (2004). Duchowość i zakorzenienie [Spirituality and rootedness]. In K. Droba, T. Malecka \& K. Szwajgier, (Eds.), Duchowość Europy Środkowej i Wschodniej [Spirituality in Central and Eastern Europe] (pp. 41-53). Kraków: Akademia Muzyczna w Krakowie.

Redepenning, D. (2002). Passion und Aufersteung. Sofia Gubaidulinas Zyklus Johannes-Passion und Johannes-Ostern. Musik-Texte, 93: 27-35.

Schmeltz, P. J. (2009). Such Freedom, if only musical. Unofficial Soviet Music during the Thaw. New York: Oxford University Press. 